\title{
Siyaset, Postmodern Kimlik ve Gençlik
}

\author{
Politics, Postmodern Identity and the Youth
}

\begin{abstract}
Abdurrahman BABACAN ${ }^{*}$
Öz

Postmodernizmin kimlikler üzerindeki etkisini incelemek, küreselleşme, kültür endüstrisi ve postFordist yaşam pratiği ile beraber düşünüldüğünde, her bakımdan modern dönemin kalıplarından sıyrılarak yeni bir düşünme, yaşama ve hissetme tarzı şeklinde ortaya çıkan bir olguyu analiz etmek demektir. Modernite ile birlikte zaten oldukça parçalanmış olan kimlikler üzerinde etkisini gösteren postmodern felsefe, zihinsel, felsefi ve kültürel dönüşüm sürecini hızlandırıp derinleştirirken, bütüncül bir siyasal içerim olarak kimlik'e yansımış, buradan da yeni bir toplumsal ve siyasal kültür inşa olmuştur. İşte bu yeni kavramsal dünya, Türkiye’nin siyasal kimlikleri açısından da oldukça dönüştürücü sonuçlar doğurmuştur. Kimlik kavramının özü dönüşüme uğramış ve siyasal alanda, ucu-sonu belli olmayan bir kimlik algısı şekillenmeye başlamıştır. Farklı tarihsel zaman dilimlerinde yapılan saha çalışmalarında elde edilen bulgular da göstermektedir ki, vatandaşlar özellikle siyasal kimlik konusunda hem bir kafa karışıklığı yaşarken; fakat aynı zamanda bilinçli ve iradi biçimde geleneksel/konvansiyonel kimlikleri erozyona uğratıp yeni bir kimlik örgüsü etrafında oluşan bir zihinsel-felsefi kavram dünyasına girmiş olmakta, bunun en net yansıma alanını ise genç kuşaklar oluşturmaktadır.
\end{abstract}

Anahtar Kelimeler: Postmodernizm, Kültür Endüstrisi, Kimlik, Siyasal Kimlik, Görelilik, Gençlik

\section{Abstract}

Postmodernism, producing a new philosophy that dictated the ending of ideologies through the realization of conjunctural marriages with various ideological perspectives, showed perhaps the deadliest effect on identities that were already quite fragmented and left homeless. The confusion in understanding of the political sphere has been reflected in identity as a holistic political inclusion, from which the political societies and political cultures have exacerbated. By understanding the politics and culture of postmodern political culture being transformed by the new conceptual world, Turkey's political identities have also been given rise to quite converter results. The essence of the concept of identity has undergone transformation and has begun to take shape in the political arena. Findings from field studies in different historical time periods also show that citizens are confused, especially about political identity; but also, a new mental-philosophical conceptual world that has been formed around a new identity bracket by eroding traditional/conventional identities in a conscious manner, in which the clearest reflection is on the young generations.

Keywords: Postmodernism, Culture Industry, Identity, Political Identity, Relativity, Youth

* Yrd. Doç. Dr., İstanbul Medipol Üniversitesi, İnsan ve Toplum Bilimleri Fakültesi, ababacan@medipol.edu.tr 


\section{Giriş}

Gerek küresel ölçekte gerekse yerel bazda son y1llarda yaşanan niteliksel dönüşüm süreci, birçok unsur gibi siyasal kimlikler üzerinde de ciddi etkiler yaratmıştır. Türkiye’nin özelde içinden geçtiği tarihsel bağlam, Cumhuriyetin ilk dönemleri açısından kendine has bir realite yaratırken, niteliksel dönüşümün başlaması ve süreç içerisinde gitgide derinleşmesi anlamında 1980 sonrası dönem, yeni bir kırılmanın izleğini bizlere vermektedir. Modern dönemin siyasal kimlik kalıplarının artık işlemediği bu yeni dönemde, postmodernizm etrafında örgülenen ve küreselleşme, kültür endüstrisi, post-Fordizm üzerinden gelişen yeni kültürel, iktisadi ve siyasi içerikle birlikte oluşan bir yeni anlam havzası, siyasal kimliklerin tarifi, anlaşılması ve pratiği üzerinde ciddi bir dönüşüm yaratmaktadır. Bu çalışma, işte bu etkileşimin Türkiye örneğinde ve bunun içerisinde de özelde gençlik düzleminde nasıl ve ne şekilde oluştuğunun ve sonuçlarının ne anlam ifade ettiğinin cevabının arandığı bir çalışma olarak kurgulanmıştır.

Teorik zeminde, modern dönem sonrası oluşan ve merkezinde postmodern içeriğin yer aldığı yeni anlam dünyası, diğer parametreler küreselleşme süreci ve post-Fordist iktisadi-kültürel sürecin oluşturduğu yeni kültür-ekonomi ve kültür-siyaset ilişkisi ile birleşerek, kimlikler üzerinde nasıl bir etki yaratmaktadır? Türkiyedeki siyasal kimlik olgusu, bu yeni bağlam dâhilinde nasıl bir etkileşim fotoğrafı sunmaktadır? Yine ideoloji tanımı ve pratiği ile ideolojik pozisyonlardaki yeni durum nasıl şekillenecektir? Cumhuriyetin ilk dönemindeki realite, 1980'ler itibariyle neredeyse büsbütün dönüşürken, bu yeni durumun doğurduğu pozitif ve negatif yönler nasıl anlaşılmalıdır? Bunun özellikle siyasal ve toplumsal kimliğin oluşup olgunlaşma evresini geçirdiği 18-25 yaş aralığı gençliğine dair ne gibi sonuçları vardır ve bu sonuçlar, nasıl okunmalıdır?

Çalışma dâhilinde adım adım cevabını aradığımız sorular bunlar olacaktır. Bu ise, hem teoriktarihsel zemin analizi, hem de bu zeminin, eldeki niceliksel bulgulara olan yansımaları ile birlikte değerlendirilecektir. Buradan çıkacak çıktı ise bize, 1980 sonrası küresel düzeyde yeşeren ve gün geçtikçe zihinsel yapılara ve pratiklere işleyen teorik havzanın ve yeni anlam dünyasının, Türkiye'deki gençlik özelinde, siyasal-toplumsal kimlik tanımları ve içeriklerine nasıl yansıdığının cevabını sunacaktır.

\section{Postmodernizm-Kimlik-Siyasallık İlişkisi}

Kimlik, hem modern hem de geleneksel dönemin en tartışılan ve üzerinde kafa yorulan, sorular sorulan meselelerinden birisidir. Zira bir tanımlama, bir aidiyet ve bir ifade biçimi olarak, insanın varoluşsal pozisyonu ile ilgili hususu belirtir. Geleneksel dönemden birçok ayrışma noktasıyla beraber belki en dikkat çekici ayrışma noktası, modern dönemin kimlikler üzerindeki yaralayıcı, parçalayıcı, savunmasız bırakıcı ve karmaşıklaştırıcı etkisidir. Zira modern dönem boyunca insanlar, siyasal kimliklerini bir çeşit ideolojik konumlarına hamletmişler, buradan da sığ ve derinliksiz bir kültürel varoluşa ulaşmışlardır. Bu sığlık, zihinler üzerinde derin tahribatlar bırakmıştır. $\mathrm{Bu}$, modernleşmenin de ötesinde, yeni bir siyaset ve varoluş tanımlaması çabasını getirmiş, bunun ilk ve öncül nüveleri, bilfiil modern zihnin üretim yatağı olan Batı düşüncesi 
içerisinde ortaya çıkmıştır. Çeşitli ideolojik perspektiflerle konjonktürel evlilikler gerçekleştirmek suretiyle, aslında dikotomik olarak ideolojilerin bitişinin de haberini veren bir yeni felsefe üreten postmodernizm, belki de en ölümcül etkisini, zaten oldukça parçalanmıș ve evsiz bırakılmış olan kimlikler üzerinde göstermiştir. Siyasal alanın anlaşılmasındaki kafa karışıklığı, bütüncül bir siyasal içerim olarak kimlik’e yansımış, buradan da buhranlı siyasal toplum ve siyasal kültürler neşet etmiştir. Bu bağlamda postmodernizm, moderniteyi aşan ve insanlığa yeni bir tasavvur dünyası vaat eden bir yeni çağın başlamış olduğu inancını yaymaya çalışır. Görelilik, muğlâklık, tekillik, parçacılık ve parçalanmışlık, çok kültürlülük ve çok kimliklilik olarak ifade edilebilecek temel karakteristikleriyle postmodern felsefe, ürettiği siyasal kültürle, kimlik meselesini sübjektif ve "özgür” bir alana çekmek suretiyle, geleneksel aidiyetlerden, disipline edici normatif çerçevelerden, ahlaki ve siyasi konumlanışlardan azade bir tasavvur ve pratikler dünyası öngörür.

$\mathrm{Bu}$ süreç, kapitalizmin yeniden yapılanma süreciyle de yakından ilişkilidir. Kapitalizmden önceki dönemlerin zaman ve mekân algısı, dolayısıyla da insan benliği algısı öngörülebilir ve ölçülebilir ölçütler içerisinde bir konum arz ederken, kapitalizmle birlikte ve hatta bunun da kendi içerisindeki niteliksel dönüşümle, zaman da mekân da insan da bu özelliğini yitirmiştir. Zira kapitalizm, bütünleşik sosyo-kültürel, sosyo-iktisadi ve sosyo-politik bir olgu olarak, tüm etkileşim konseptlerini de kendi ölçütü ekseninde yeniden tanımlar ve şekillendirir. Bu, sadece iş dünyası ya da çalışma hayatıyla sınırlı bir durum olmayıp sosyal yaşam, psikolojik bağlam ve kültürel etkileşim süreçleri ve tüm politik ilişkileri de içine alan, geniş kapsamlı bir süreçtir. Bu anlamda, evvela bir zihin formu sorunu karşımıza çıkmaktadır. Kimlik meselesine doğrudan -ve çoğu zaman da negatif olarak - yansıyan bu durum, yeni bir insan tipi üretmek gibi bir neticeyle, bu yeni zihinsel duruma dair bazı sonuçlar üretmektedir.

Jameson, bu yeni postmodern kültürü, geç-kapitalizm döneminde ekonomi-kültür ikilisinden yola çıarak tanımlamak ve anlamak gerektiğini ifade eder (Jameson, 2008, s.32); ki bu tarifte küresel kapitalizmin küresel kültürle girdiği karşılıklı etkileşim, postmodernizmin kuramsal ve pratik zemininin belirleyicisi ve aynı zamanda hazırlayıcısıdır. Bu zeminin bugünün kavramsal dünyasına yansıması ise, günümüz dünyasındaki en popüler kavramsal çerçeveler olan demokrasi, özgürlük ve insan hakları nosyonlarının da kendisine göre yeni bir anlam içeriği kazanmış olmaları ve postmodern kültürün belirleyicileri olan küresel kapitalizm ve küresel kültürün ideolojik altyapısı olan piyasa ideolojisi ile eklemlenerek, yeni bir zihinsel havza inşa etmiş olmasıdır.

Frankfurt Okulu teorisyenleri ve özelde Gramsci’nin sıklıkla vurguladığı bu yeni bağlam, kendine özgü yaşama, düşünme, tanım yapma, hissetme tarzını da beraberinde içsel olarak inşa etmektedir (Gramsci, 1971, s.506). Edward Carr yarım asrı aşkın bir zaman öncesinden, gelişmekte olan yeni duruma dair yaptığı değerlendirmede, endüstri öncesi dönemin toplumsal alışkanlıklar ve saiklerinin aynen devam edeceğinin elbette ki düşünülemeyeceğini belirtirken, son bir asır içerisinde endüstrinin çarklarının dönmesini mümkün kılmış felsefe, alışkanlıklar ve saiklerin bir toplumsal form ve yapı üretme noktasındaki başarısını vurgulamıştır (Carr, 1957, s.81-98). Benzer şekilde Habermas insanlığı, kapitalizmin büyüyen mantığının ulaşacağı 
nokta ve günümüz yaşantısının gerçek yapısının oluşması konusunda uyarırken, ulaşılacak olunan bu noktaya yaşamın sömürgeleştirilmesi adını vermektedir. Yani profesyonel yaşamın aracılaştırılması, işyerinin hareketli hale getirilmesi, rekabet ve performans ölçümlerinin ilkokula kadar yaygınlaştırılması, hizmetlerin, ilişkilerin ve yaşama yerlerinin paralı hale getirilmesi, kişisel yaşam alanlarının tüketici anlamda yeniden tanımlanması, özel ve resmi olmayan eylem alanlarının yasal düzenlemesi ve bürokratikleştirilmesi ve her şeyden öte genel olarak okul, aile eğitimi ve kültürel yeniden üretimin politik yönetimlere dâhil edilmesi, tekil bir insanın yaşam alanının tümünün birden, yeni anlam ve yaşam tarzı tarafından kuşatılmasının alt unsurları olarak belirmektedir. Beraberinde ise, günümüz toplumlarında kapitalist sistemin, deneyimleri ve insani ilişkileri metalaştırmakta ve bir zamanlar resmi olmayan ve demokratik denetime açık olan ya da bireylerin kendilerine bırakılan yaşam alanlarını resmi olarak düzenlemekte olduğunu ifade etmektedir (Habermas, 2001, s.776; Habermas, 1994, s.315).

Neo-Marksist okulun tanımlamasıyla kültür endüstrisi dönemi, postmodern felsefenin postFordist süreç birlikte yarattığı bu yeni zemin bağlamında değerlendirilmelidir. Gerek zaman, gerek mekân, gerekse insan algısının niteliksel bir dönüşüm geçirdiği bu yeni felsefi ortamın, bu bakımdan, ayrı bir önemle üzerinde durmak gerekmektedir. Zira postmodernizme atfedilen önem ve cazibe, toplumdaki ve insandaki değişmelere yeni bir anlam ve tanım koyma çabasından kaynaklanmaktadır. Featherstone, bu bağlamda, toplumsal yapılar ve ilişkilerdeki dönüşümün temel hazırlayıcısı olarak gördüğü postmodernizmin nasıl bir tanım ve anlam sahası inşa ettiğini şu şekilde izah etmektedir:

- "Batı modernliğinin bilim, hümanizm, sosyalizm vb. nosyonlarla imtiyazlı evrensellik iddialarının yaslandırıldığı temel üst-anlatıların sakat olduğunu ve entelektüellerin kendinden emin yasa koyucu rolünü terkedip yorumlayıcı rolüne soyunmasından ötürü yerel farklılıklara daha duyarlı ve daha az gösterişçi bilgi tarzlarına yönelmemiz gerektiğini öneren felsefe, toplum ve kültür teorilerinde temelcilik karşıtı bir konum.

- Yerel ve bölgesel alanın bu şekilde imtiyazlı kılınması akademi içerisinde, entelektüel ve sanat çevrelerinde simgesel hiyerarşilerin demokratik ve popülist bir çöküşüne tercüme edilir ve böylece sözgelimi yüksek kültür ve popüler ya da kitle kültürü arasındaki, sanat ve gündelik hayat arasındaki ayrımlara itiraz edilir.

- Bu boyutlar "postmodern derinliksiz kültür" (Jameson, 2008) ibaresinde düzenli tarihsel gelişme nosyonunun yerini, geçmişin esaslı bir düzen ya da değer yargısı üretilebilecek bir noktanın keşfedilmesine izin vermeyecek şekilde, bitimsizce çoğaltılan ve simüle edilen imajlar, fragmanlar ve gösterilerin yığılması olarak algılanmasına bırakması gerektiğini belirten nosyonda özetlenir” (Featherstone, 1996, s.164).

Bu meyanda postmodern söylemin, gerçekleşen kapitalist dönüşüm süreciyle birlikte, yerleşik siyaset kuram ve paradigmasını önemli ölçüde dönüştürdüğü belirtilebilir. Söz konusu bu dönüşümlerin yaslandığı temel nokta, siyasal kuramda modernite etkisinin içinden geçilen siyasal meselelere dair bir şey söyleyemeyişi, fakat daha sorunlu biçimde yansıdığı temel alan ise kimlik 
sorununu bireyden topluma hemen her düzeyde ortaya çıkarması olmuştur. Kimlik sorusuna özelde geçmeden önce, meselenin siyasal alana taalluk eden boyutuna değinmekte fayda vardır. Zira postmodern felsefenin siyasal bağlamı yeniden tarif ve hatta içeriklendirme gayreti, esasında geçirilen zihinsel, felsefi ve kültürel dönüşüm sürecinin siyasal alana olan yansımasıdır ve bu izaha kavuşmadan, kimlik-siyaset ilişkisinin bu dönemde ele alındığ yeni çerçeveyi anlamak mümkün olmayacaktır.

Batı siyasal düşüncesinin siyaset ayrımlarını konu edinen genel çerçevesi, liberal, liberal demokrat ve Marksist olmak üzere üç ana ayrım noktasından yola çıkar. Postmodern siyaset anlayışının ise, ne orta sınıf ne de işçi sınıfına, daha ziyade burjuvaziye yakın bir pozisyon tutarak, kendine en yakın siyasal pozisyon olarak liberal birey, toplum ve devlet modelini seçtiği söylenebilir. Bu, ona çok geniş bir hareket alanı açmak suretiyle, ilkesel olduğu kadar işlevsel bir rahatlık da sunar. Beraberinde, gerek birey, gerek toplum, gerekse devlet düzeyindeki siyaset alanının özellikle 90’larla birlikte iliklerine kadar hissettiği küreselleşme sürecini bu felsefi bakışla eşgüdümlü değerlendirmek zaruridir. Zira ulus-devlet zihinsel, siyasal, kültürel, sosyolojik ve ekonomik kalıplarını aşmadan düşünülecek bir siyasal bağlam konsepti, bir nevi anakronizme yol açar. Bu yeni siyasal paradigma için küresel bir zihne; ve dolayısıyla da küresel bir ekonomi, kültür, sosyoloji ve siyaset ufkuna ve zeminine ihtiyaç vardır. Yukarıda ele alınan Post-Fordist dönem olarak da nitelenebilecek geç-kapitalizm döneminin, birçok parametreyi bünyesinde barındırmak suretiyle hayatın hemen her alanına dönüştürücü bir etkiyle sirayet ettiği hususu da yine bu bağlam dâhilinde zikredilmelidir. Yeni dönemle birlikte bireye ve ekonomiden kültüre hemen her alanda bireysel çerçevede gelişecek oluşumlara dair sınırsız kredinin açılması, devletin birçok husustaki belirginliği ve kaynak dağılımlarındaki rolünü minimize edecektir. Bu ise, postmodern siyaset teorisyenlerinin iddiasıyla, yatay ve eşitlikçi bir siyasal alan anlamına gelir. Bu yatay durum, kültürel kimlik tanımlamalarının da yeniden ele alınmasını getirmektedir. Farklılık ve çoğulculuğa vurgu ve katılımcılık gibi yeni fikirsel tanımlamalar ortaya çıkmakta ve bu, yeni bir siyasal kültürü işaret etmektedir. Eski tip ulus-devlet sınırlamalarına hapsedilmiş kimliksel tanımlama biçimleri yerini, global bir çerçeve içerisinde, kamu-özel, alt kültür-üst kültür gibi ayrımlara karşı olan bir yeni kültürel çoğulculuk anlayışına bırakmıştır. Bu anlamda, azınlıkların varlığını pekiştiren, keskin ve ayrıştırıcı olarak nitelediği ideolojik pozisyonları reddeden, ulusalcılı̆̆ı ilga edip etnik ve dini azınlıkları ön plana çıkaran, dil, din vb. argümanlar üzerinden getirilebilecek bir birlik olgusuna toptan ve kategorik olarak karşı çıkan postmodernizm, yakınsadığı liberal pozisyon ile de, bu pozisyonun kurumsal aktörü olarak liberal devlet anlayışı ile de siyasete ve siyasal kimliklere bakışı köklü biçimde etkilemiştir. Liberalizmin temel değerleriyle çok sıkı bir yakınlık içerisinde, devlete ve devletin kimliklere dair biçmeye çalıştığı uygulamalara tepkisel duruş koyarak, bu argüman üzerinden kimliklere aidiyet bağlarını da sorgulayan söz konusu yeni düşünce havzası, her şeyi göreli hale getirdiği gibi, insanı ve insanın kendisini tanımlama ve anlamlandırmasının en temel belirleyici parametresi olarak kimlikleri de göreli hale getirmiş, muğlaklaştırmıştır. 
Postmodernizmde toplum yaşamında ortaya konulan düşünce, her zaman önceden belirlenmiş katı kuralları uygulamaktan ziyade nasıl hissediliyorsa öyle yaşamayı öngörmektedir (Küçük, 1994, s.303).

Artık eski dönemlerde olduğu gibi ekonomik refahın birleştiriciliği, siyasal bütünleşme ve/ya kültürel bağlilıklar tezleri, bugünün postmodern anlatısında kendisine yer bulamamaktadır. $\mathrm{Bu}$ durumda insanın aidiyeti ve bağlılığı, birtakım üst anlatılara ve değerlere ve bu değerler üzerinden oluşan kültürel/dini/toplumsal yapılara değil, belirli alt grupsal yapılanmalara -ki "topluluk" olarak da ifadelendirilebilir - dönük olacaktır. Hızlı değişen bir toplum özelliğiyle postmodern toplum, klasik anlamda toplumun örgütlenme temelini de topluluk şeklindeki alt grup kümelerine döndürmüştür. Teknoloji ve bilginin bu yeni örgütlenme temelinin esaslarını oluşturması, beraberinde, dünya genelindeki bir tektipliğe de kapı açmaktadır. Yani bir yandan alt kimlik özellikleri ortaya çıkıp belirginleşirken, bir yandan da kimlikler özgün değerlerini yitirmeye ve bir homojen kimlik içinde emilmeye başlamıştır. İletişimdeki gelişmeler, farklı toplumların farklı kimlik aidiyetlerine sahip insanlarını aynı kodu kullanmaya itmiş; insanın kendi özgün kimliğini bulması zorlaşmıştır. Bu, elbette ki ulus-devlet sınır ve mantığını aşan bir durumdur. Özellikle etnik ve bölgesel kimlik siyasetindeki artış, ulus-devletin eski tip siyasal kimliklere vurgu yapan yapısını çözmeye başladığının önemli bir göstergesidir. Etnikliğe ve bölgeselliğe yönelik artan bu ilgi, siyasal, ekonomik ve kültürel küreselleşme bağlamında, ulusların artık anlamlı bir kolektif kimlik veya sosyal aidiyet hissi sağlamada etkili olamadığ 1 gerçeğini ortaya koymaktadır (Heywood, 2007, s.249).

Söz konusu yeni siyasal bağlam, sivil alana özel bir anlamın yüklenmesini de içermektedir. Eski görece dar, kapalı ulus-devlet mentalitesi ve sınırlarındaki siyasal alan, sivil alanın içeriğini de kapsayan, bu yönüyle sivil unsurların hareket alanı anlamında kendilerini ifade ediş ve ortaya koyuşlarına yapısal bir sınırlama getiren bir çerçeveye işaret ederken yeni siyasal bağlam, bundan böyle her türden kimlik tanımlama ve pratiklerinin devlet içinde değil sivil toplumda yaşanması, bu anlamda da, devletten ayrı bir alan olarak sivil toplumun çoğulculuğu ve farklılığı kapsaması gerektiği savından hareket eder.

Kimlik meselesinin, bir kültürel değişim ekseninde postmodernizmle beraber düşünülmesinin önemi, kültür-siyaset ilişkisinin değișen niteliğinde aranmalıdır. Modern dönemde kültür siyasal'ın bir parçası olarak görülürken, postmodernizm kültüre, siyasal'ın belirleyicisi olarak bakma eğiliminde olmuştur. Yani kimlik artık tanımlanan ve belirlenen bir olgu olmaktan çıkmış, kendi kendisini tanımlayan bir forma bürünmüştür. Postmodern kültür ile gelen kimliğe dair bu yeni tanımlama özelliği ise sivil-temelli bir anlam, içerik ve misyon ile kodlanır. Devlete karşı özgürleşmenin aracı olarak görülen kimliğin bu tanımı, siyasal alanı tanımlarken oldukça önemli bir yer işgal eder. Zira çoğulculuk ve farklılık, bu yeni kimlik politikası ve siyasetinin bir ve pozitif anlamlar yüklenen tarafında yer alırken, öte tarafında ise Jameson’un belirttiği, kimliği ve kimlik politikalarını sivil bir özgürleşmeden çok, küresel ekonomik bağlamın bir ideascape’i olarak, tektipleşen kültür anlayışının önemli unsurlarından biri olarak gören bakış yer almaktadır. 
$\mathrm{Bu}$ anlamda, postmodernizmin kimlik meselesine belki de en ciddi biçimde taalluk eden tarafı, çağdaş kültürde çoğulculuk ve farklılık içerisinde kimliğin buharlaşmasına yaptığı tersten katkıdır. Şaylan, bu durumun oluşmasını hazırlayan zemine dair yaptığı kategorilendirmede, geleneksel kimliğin karşısında etnik, dinsel ya da mezhepsel temelli, yeni kimliklerin en gelişmiş ve zengin toplumlarda bile oldukça fazla ortaya çıkmasının, siyaset kuramının yerleşmiş paradigmalarının yetersizliğinin sonucu ve aynı zamanda kanıtı olduğunu belirtir (Şaylan, 2002, s.301).

\section{Türkiye Resmin Neresinde?}

Siyasal kültürünün postmodern siyaset ve kültür anlayışı tarafından dönüşüme uğrayarak, içinden çıkardığı yeni kavramsal dünya, Türkiye’nin siyasal kimlikleri açısından oldukça dönüştürücü sonuçlar doğurmuştur. Kimlik kavramının özü dönüşüme uğramış ve siyasal alanda, ucu-sonu belli olmayan bir kimlik algısı şekillenmeye başlamıştır. Postmodernizmi, bu anlamda, apolitik ya da anti politik değil, daha çok, özgül ve özgün bir politika türü olarak tanımlayan Heywood onu, bir umut dalgası ya da bir umutsuzluk gibi ayrımlara gitmeyen kültürel ve felsefi bir hareket olarak tarif eder (Heywood, 2007, s.92). Postmodern kültür parçalanmayı savunurken, bir nevi özgürlük adına ister toplumsal, ister bilgisel her türlü bütünleşmeyi hor görür, dışlar. $\mathrm{Bu}$ özgürleşme iddiasını Rorty şöyle ifade eder:

"Yüceliği isteyenler postmodernist bir entelektüel hayat biçimini amaçlamaktadırlar. Güzel toplumsal ahenkler isteyenlerse, bir bütün olarak toplumun kendi kendisini temellendirme kaygısıyla canını sıkmaksızın kendisini teyid ettiği bir postmodernist toplumsal hayat biçimi istemektedir" (Rorty, 1994, s.169; akt. Aslan ve Y1lmaz, 2001).

İdeoloji ve ideallerin, bu yeni durum içerisinde nereye tekabül ettiği de ayrı bir önemli noktadır. Tabiatı itibariyle herhangi bir ideolojik pozisyona yakınlık duymayan postmodern durum, kendisi etrafında şekillenen bir siyasal alana ideolojisiz ve -kendi iddiasıyla - tarafsız bir dünya vaat etmektedir. Belki buradaki kritik nokta, bunun gerçekte tarafsızlık pozisyonu anlamına gelip gelmediğidir. Şaylan’ın da ifade ettiği gibi bu bilakis her türlü siyasi yönelime uyabilecek kadar soyut ve bulanık bir olgu olduğunu da gösteriyor olabilir (Şaylan, 1996, s.6); zira bütünlükten yoksun oluşu ve herkesin onda kendisine ve yönelimine uygun eklektik formlar üretmesine ve bulmasına kapı açan gevşek karakteri, onun bir bakıma zayıflığı olduğu kadar, bir anlamda belki de güçlü tarafını oluşturmaktadır. Geleneksel modern kabulün aksine, epistemolojik sürecin gerçeğe birebir tekabül etmediğini ve bu anlamda, gerçeğin sürekli biçimde yeniden üretildiğini iddia eden postmodern durum, gerçeklik ve hakikat algısını felsefi sorgulamadan geçirerek, aslında yıkıma uğratır. İnsanların hakikate dair algılarının buharlaşıp içeriğinin görelileşmesi ise, insana "yeni özgürlük alanları" açar. Geleneksel modern dönemin, bir kimlik üretme anlamında en temel parametrelerinden sayılan ideolojiler de, bu çerçeve içerisinde görelileşir ve içerikleri, bir takım eklektik süreçlere girmek suretiyle özgül ağırlığını kaybeder. Bir bakıma eskatoloji üretme dönemi olarak 60’lı yıllarda “ideolojilerin sonu”nu ilan ederek başlayan süreç, 70 ve 80 'lerde ise yeni Fransız düşüncesiyle birlikte "insanın sonu”nu ilan ederek devam etmiş 
(Topçuoğlu ve Aktay, 1996, s.10); yani, eski dönemin mahsulü, yeni dönemin hegemonya arac1 ideolojik kalıpların tümüne; proleteryaya, devrime, hümanizme; kısacası Lyotard’ın sonradan "meta anlatılar" olarak niteleyeceği bir sürü ideâle olduğu kadar, insan’a dair özgünlükler ve hasletlere vedayı da getirecek bir zihinsel ve felsefi ortama evrilmiştir.

O halde Türkiye bu değişimin neresindedir? Yukarıda da ifade edildiği gibi Türkiye’nin siyasal kültürünü de derinden etkileyen bu süreç, kimlik meselesi, siyasal kimlikler ve kimlik siyaseti etrafında birtakım dönüşümlere kapı açmıștır. Kimlik politikalarına sivil bir anlam ve gaye yükleyen liberal perspektiften bakıldığında, yukarıdan kural ve tanım koyucu, kimliği üstten belirleyen devlet kaynaklı politikaların, demokratikleşme sürecine darbe vurduğu savı sunulabilir. $\mathrm{Bu}$, bir anlamda doğru ve haklı bir zemini olan da bir kaygıdır. Zira Cumhuriyetin kurulduğu yıllardan itibaren ortaya konan devlet-merkezli siyasallık ve kimlik tanımları, hep bir baskı, icbar ve şekillendirme siyasetini doğurmuş, sivil alana ve ferdi kimliksel tanımlara yer verilmemiştir. Bu yönüyle Türkiye'nin tek parti dönemi ile başlayan modern tarihi, tek merkezden tanım koyma, yaklaşık her on yılda bire tekabül eden darbe "geleneği”" ve devletin vatandaşlık tanımlamaları ve kimlik siyasetine direkt müdahil oluşunun tarihidir. Kentli ve kırsal halkı tek tip bir vatandaşlık eğitiminden geçirmek suretiyle sisteme eklemlemeyi hedefleyen söz konusu süreç, katı bir hak-vazife dengesi üzerinden devlet eksenli bir yurttaş tipini ortaya çıkarmayı amaçlamıştır. Üstel'in ifadesiyle bu, rejimin doğrudan devlete sadık (makbul) vatandaşı ve dolayısıyla da bu vatandaşlardan oluşan bir ulusu inşaya soyunmasıdır. Etno-kültürel yönelimli bir bürokratik milliyetçilik anlayışı ile sözleşmeci ulus söyleminin tayin ettiği bu yurttaş tipi, bugüne kadar Türkiye'deki yurttaşlık eğitiminin karakterini belirlemiştir (Üstel, 2014, s.229). Özellikle 1950’ye dek süren tek parti döneminin tam anlamıla karakterize edildiği böylesi bir durumdan, 1980 darbesine dek, çok partili dönem boyunca daha ılımlı ve hatta liberal sayılabilecek bir yumuşama çizgisine geçildiği söylenebilir.

1980 sonrasını ise konumuzu izaha kavuşturan birkaç farklı boyutu barındırması bakımından bütünlüklü biçimde değerlendirmek gerekmektedir. Devletin darbe ile birlikte yeniden militan bir çizgiye geçip, emredici ve dikte edici karakterine dönmesi, en çok siyasal bağlamı ve onunla direkt ilişkili kültürel sahayı; ve bu ikisinin bir anlamda kesişim kümesinde yer alan siyasal kimliği etkilemiştir. Bu etki ise, bu defa, 1980 öncesindeki benzer devlet merkezli süreçlerin yaşattığı etkiden daha farklı bir seyir izlemiştir. Nitekim 1980 sonrası dönemle birlikte, resmi ideolojilerin nasıl aşılacağı ile ilgili temel arayışların da içerildiği; etnik, dini, ideolojik ve kültürel kimliklerin artık bir merkezden belirlenemeyen ve yönlendirilemeyen bir yapıya kavuşmasının "bağımsızlaşma" olarak alkışlandığı bir döneme girilmiştir. Bu, başlı başına niteliksel bir dönüşüm demektir. Beraberinde, yukarıda da değinildiği üzere, küresel kapitalizm ile küresel kültürün ortak bir alanda belirleyicisi olduğu postmodern kültür ve bunlara esas zemini teşkil eden piyasa; demokrasi, sivil siyaset, insan hakları ve özgürlük gibi kavramsal nosyonlar etrafında, yeni bir zihinsel havza oluşturmuştur. Söz konusu dönem, bu yönüyle, tam da eski mantalitenin en keskin biçimi ile, yeni mantalitenin ılımlı ve esnek içeriğinin çok ilginç bir karşılaşması olmuştur. Bu karşılaşmanın galibi ise, yine postmodernizm eliyle karmaşıklaşmıştır. Gerek Foucault, gerek Baudrillard'da görülen, iktidarın devlet ya da silahlı kuvvetler gibi 
baskın kontrol merkezlerinden uzaklaşıp dağılmasının, merkezi gücün çözülmesi değil, aksine pekişmesi olabileceği; iktidarın her türlü muhalefete direngenliğini arttıran zira karşı koyuşun her biçimini önceden görüp kuşatabilme olanağına sahip bir sistem halinde sarmallanışa sahip hale geldiği görüşü de, konumuz dâhilinde, olayın çok boyutlu olduğunu ifade eden bir noktaya temas etmesi bakımından önemlidir (Foucault, 2016; Baudrillard, 2003). Fakat her halükarda bu karşılaşmadan postmodern durumun galip çıktığı söylenebilir. O halde bunun, Türkiye ölçeğinde genç kuşaklar ve bu kuşaklara zihinsel yansımaları anlamında karşılığı nasıl olmuştur?

\section{Genç Kuşak ve Yansımalar}

Öncelikle vurgulanması gereken bir nokta var: 1980 sonrası dönemin bu bambaşka mahiyete sahip karakterinden bahsediliyorsa, konumuza dönem ve kuşaklar anlaminda taalluk eden yaş grubunun, 30 yaş altı grubu olduğunu görmek gerekir. Daha ziyade 18 ile 25 yaş aralığı, bunun en net göstergesinin alınacağı yaş aralığı olacaktır. Zira küresel yeni durum olarak tarif edilen zamansal bağlamın, tam da bu kuşak açısından önemli bir etki alanı yaratmış olması beklenir.

Bu bağlamda, konumuzu değerlendirirken, yukarıda çizilen teorik çerçevenin, niceliksel bulgulara olan yansımalarından bahsetmek isabetli olacaktır. Zira özellikle genç kuşak açısından, 1980 sonrası başlayan ve 2000'li yıllarla birlikte zirvesini bulan küresel konjonktürdeki baş döndürücü değişimin etkileri, Türkiye örneğinde yeni bir siyasal, kültürel, toplumsal, iktisadi ortamın da yeşermesiyle birlikte düşünüldügünde hayli önemsenmesi gereken sonuçlarının olacağı muhakkaktır. Özellikle konumuz dâhilindeki kimlik meselesi, toplumun hemen her grubu, özelde ve en kuvvetli şekilde ise -değişkenlik katsayısının yüksek olmasından ötürü gençliğin, kendisini tanımlarken ve bu tanımdan yola çıkarak siyasal ve kültürel gelişmelere yaklaşırken başvuracağı temel referans noktası olacağından, bunun mahiyetine dair nereye gelindiğinin analizi, hayati bir husustur.

Bu bağlamda, yapılan son zamanlardaki en kapsamlı kamuoyu saha araştırması mahiyetindeki birtakım çalışmaların sonuçlarına başvurmak, teorik çerçevenin toplumsal anlayışlar ve kimliklerdeki pratik zihinsel yansımalarını görmek bakımından faydalı olacaktır. Bu çerçevede Türkiye Ekonomik ve Sosyal Etüdler Vakfı (TESEV), bir öncekini 1999'da, yani özelde Türkiye’nin siyasal, iktisadi, kültürel ve sosyolojik anlamda oldukça çalkantılı geçirdiği sürecin tam içinde, toplumdaki kimlik, siyasal gelişmeler, din vb. faktörlerin nasıl bir algı sunduğunu izaha dönük yapmış olduğu kamuoyu araştırmasını, yeni bir döneme girişin ortasında, 2006'da, yenilemiş ve hem özerk hem de aynı zamanda karşılaştırmalı bir analize de imkân tanıyan bir fotoğraf sunmayı amaçlamıştır. Türkiye nüfusunu temsil niteliğine sahip bir örneklem iddiasıyla 1492 kişiyle yüz yüze kendi hanelerinde anket gerçekleştirmek suretiyle oluşturduğu söz konusu çalışmada, daha önce 1999 yılında yapmış olduğu araştırmanın devamı niteliğindeki sorularla toplumun geçen zamanın getirdiği dönüşümle birlikte değişen algılarını ölçmeye dönük bir perspektif koymaya çalışılmıştır (Çarkoğlu ve Toprak, 2006). 
Sonuçların ve verilen cevapların konumuza taalluk eden kısmına bakıldığında çarpıcı rakamlar görmekteyiz. Buna göreözelliklekendilerini ilkin ve öncelikle nasıl ve hangi sıfatla tanımladıklarına dair soruda 18-24 yaş grubunun vermiş olduğu cevaplara bakıldığında, “öncelikle Türk” olarak tanımlayanların yüzde 17,6, “öncelikle Müslüman” olarak tanımlayanların yüzde 38,6, "öncelikle Türkiye Cumhuriyeti vatandaşı” olarak tanımlayanların yüzde 32,7, “öncelikle Kürt” olarak tanımlayanların yüzde 5,1, “öncelikle Alevi” olarak tanımlayanların ise yüzde 2,6 lık bir orana sahip olduğu sonucu çıkmıştır. Bu durum, özellikle Türklük tanımlaması ve aidiyetinde gençler arasındaki görece azalmış olan ağırlık ve etkiyi göstermesi bakımından vurguya değerdir. Bunun yerini, zamanla küresel ve yerel konjonktürün etkisiyle Türkiye cumhuriyeti vatandaşlığı gibi daha üst bir kimlik tanımlaması almaya başlamıştır. Bu vatandaşlık aidiyetini ifade eden içeriğin anlamlı bir ağırlığının aynı zamanda etnik köken olarak Türklerden oluşması da, konunun geldiği noktayı göstermektedir. Bununla birlikte halen daha kendisini ilkin bir etnik kökene refere eden gençlerin, Türk-Kürt toplamda yüzde 22 gibi bir orana sahip olduğu da vurgulanmalıdır. Bu ise, hem belli bir bölgeselleşmeye işaret eden bir trende, hem de birtakım refleksif ve reaksiyoner tutumlara ilişkin olmalıdır. Fakat yine de, ne olursa olsun görülen odur ki, şu ana dek toplumsal manzara içerisinde, dominant etnik unsur tanımlama ve aidiyetinde bir gerileme söz konusudur. Bu da yukarıda çizilen teorik çerçeveyi doğrulamaktadır.

Gençlikten toplumun geneline geçildiğinde ise, sonuçların konvansiyonel ve geleneksel Türkiye toplumsal durumuna daha yakınsadığını görmekteyiz. Yani gençler arasında net biçimde görülen farklılaşma trendi, - gerek yaş ve diğer faktörler bakımından - toplumun geneline hasredildiğinde çok da net görülmemektedir. Yani şu ana dek Türkiyedeki siyasal sosyolojinin bulgularına benzer şekilde, gerek aidiyet duyulan partiler bakımından, gerek săg-sol şeklindeki ideolojik pozisyonlanmalar bakımından, gerekse laik-İslamcı ayrımı esasından durum, geleneksel bulgulara benzerlik arz etmektedir.

Buna göre, kendilerini; “öncelikle Türk” olarak, “öncelikle Müslüman” olarak, “öncelikle Türkiye Cumhuriyeti vatandaşı” olarak, "öncelikle Kürt” olarak, “öncelikle Alevi” olarak tanımlamada, en son seçimlerde oy verilen partiler nezdinde bakıldığında,

AK Parti seçmeninin;

“öncelikle Türk”e verdiği cevap yüzde 14,6

“öncelikle Müslüman”a verdiği cevap yüzde 60,0

“öncelikle Türkiye Cumhuriyeti vatandaşı”na verdiği cevap yüzde 23,1

“öncelikle Kürt”e verdiği cevap yüzde 0,9

ANAP-DYP-DP çizgisi seçmeninin;

“öncelikle Türk”e verdiği cevap yüzde 34,8

“öncelikle Müslüman”a verdiği cevap yüzde 32,9

“öncelikle Türkiye cumhuriyeti vatandaşı”na verdiği cevap yüzde 32,3 
MHP-BBP çizgisi seçmeninin;

“öncelikle Türk”e verdiği cevap yüzde 35,6

“öncelikle Müslüman”a verdiği cevap yüzde 28,9

“öncelikle Türkiye Cumhuriyeti vatandaşı”na verdiği cevap yüzde 35,5

CHP seçmeninin;

“öncelikle Türk”e verdiği cevap yüzde 27,7

“öncelikle Müslüman”a verdiği cevap yüzde 20,9

“öncelikle Türkiye Cumhuriyeti vatandaşı”na verdiği cevap yüzde 46,1

“öncelikle Alevi”ye verdiği cevap yüzde 2,7

DTP-BDP-HDP çizgisi seçmeninin;

“öncelikle Türk”e verdiği cevap yüzde 4,8

“öncelikle Müslüman”a verdiği cevap yüzde 20,4

“öncelikle Türkiye Cumhuriyeti vatandaş»na verdiği cevap yüzde 4,4

“öncelikle Kürt”e verdiği cevap yüzde 57,0

“öncelikle Alevi”ye verdiği cevap yüzde 11,1'dir.

Mensubu olduklarını belirttikleri siyasal-ideolojik konumlanma esasında bakıldığında ise,

Kendisini daha çok laik olarak tanımlayanların;

“öncelikle Türk”e verdiği cevap yüzde 27,2

“öncelikle Müslüman”a verdiği cevap yüzde 17,8

“öncelikle Türkiye Cumhuriyeti vatandaşı”na verdiği cevap yüzde 44,1

“öncelikle Kürt”e verdiği cevap yüzde 1,3

“öncelikle Alevi”ye verdiği cevap yüzde 4,4

Kendisini İslamcı olarak tanımlayanların;

“öncelikle Türk”e verdiği cevap yüzde 15

“öncelikle Müslüman”a verdiği cevap yüzde 60,7

“öncelikle Türkiye Cumhuriyeti vatandaşı”na verdiği cevap yüzde 19,5

“öncelikle Kürt”e verdiği cevap yüzde 3,5

“öncelikle Alevi”ye verdiği cevap yüzde 0,3 
Kendisini ne laik ne İslamcı olarak değil, daha ziyade ortada bir pozisyonda tanımlayanların;

“ öncelikle Türk”e verdiği cevap yüzde 21,6

“öncelikle Müslüman”a verdiği cevap yüzde 33,3

“öncelikle Türkiye Cumhuriyeti vatandaşı”na verdiği cevap yüzde 39,3

“öncelikle Kürt”e verdiği cevap yüzde 3,2'dir.

Toplumsal yapının genelinden çıkan bu sonuçlar göstermektedir ki, genç kuşak, burada toplumun genel tutum ve algısından bazı noktalarla ayrışmaya başlamaktadır. Hemen bütün siyasal-ideolojik pozisyonlanmaları içermesi bakımından, oy verilen/yakın durulan siyasi partiler esasından bakılarak, toplumun siyasal sosyolojisine dair genel geçer ve üstten bir kıyaslama yapıldığında, toplumun genel ortalamasının ilk kimlik tanımlamasındaki “Türklük” vurgusunun, salt gençlik grubunun buna verdiği cevaba oranla çok daha yüksek oluşu; yine, ilk kimlik tanımlamasında "Kürtlük" vurgusunun genç kuşakta, toplumun genel ortalamasına göre daha yüksek olması, geleneksel ve konvansiyonel kimlik algı ve tanımlamasında ciddi bir farklılaşmanın izlerini göstermektedir. Bununla birlikte, ilk kimlik tanımlamasında kendisini "Müslüman” olarak tanımlamakta genç kuşağın oranının, Türkiye toplumun genel ortalamasından yine önemli sayılabilecek düzeyde yüksek olduğu da dikkat çekmektedir. $\mathrm{Bu}$, aslında genç kuşak arasında Müslümanlık vurgusunun, sanılanın aksine, önemli bir parametre olduğunu göstermektedir. Yine, “Türkiye Cumhuriyeti vatandaşlığı” gibi son dönemlerde hızlı bir yükselme ivmesine giren bir kimliksel tanımlama biçiminin, hem genç kuşak hem de toplumun geneli açısından yükselmekte olan bir trende sahip olduğu da gözlenmektedir. Burada da yine genç kuşağın bu kimliksel tanımlamaya, toplumun genel ortalamasına göre daha yakın durduğu net olarak görülmektedir. Yani ilk kimliksel tanımlamalar göstermektedir ki, daha küresel, daha liberal ve aynı zamanda da belki de paradoksal olarak daha "direnişçi” ve "bölgeselci" bir kimliksel duruş, genç kuşak arasında yaygınlaşma trendindedir. Bu ise, postmodern felsefe ve küreselleşmenin, küresel kültür-geç kapitalizm ilişkisiyle birleştiğinde zihinlere sunduğu biraz karmaşık yeni durumu özetlemektedir.

Bu nokta, meseleye dair bir başka çalışma olan Sosyal, Ekonomik ve Kültürel Araştırmalar Merkezi (SEKAM) bünyesinde; 179 kentsel, 173 kırsal olmak üzere toplamda 352 yerleşim biriminde 1528 yaş aralığındaki 5541 gençle yüz yüze anket gerçekleştirilmek suretiyle hazırlanan gençlik çalışmasındaki verileri de değerlendirmemizi gerektirmektedir (SEKAM, 2013).

Buna göre, sorulan soruda, gençlerin kendilerini ne olarak tanımladıkları sorusunda, ilk 4'te yüzde 39,4 ile "Müslüman"; yüzde 27,9 ile "insan”; yüzde 19,3 ile "Türk"; yüzde 12,1 ile "Türkiye Cumhuriyeti vatandaşı" bulunmaktadır. Onları sırasıyla "Kürt”, "Alevi” ve diğer kimliksel gruplar izlemektedir. Burada önemli gördügüumüz bir nokta, bu çalışmada dâhilinde kişilere verilen cevap tercihlerinde, TESEV raporunda yer almayan; "insan” gibi çok geniş, ideolojik pozisyon ve bir kimliksel duruş itibariyle net, belirgin bir açıklığa sahip olmayan ilave bir seçenek hakkı daha konmuş olması ve buna anlamlı bir karşılığın gelmiş bulunmasıdır. Rakamlar genel fotoğraf 
anlamında, belki de TESEV raporunda ortaya çıkan sonuçlara çok benzer bir genel resim sunmasının yanı sıra, bundan farklı olan, "insan” kategorisinin her bir kimliksel tanımlama biçiminden belli yüzdeler alması; ve bu sayede, kendi başına oldukça ciddi denebilecek bir orana tekabül etmesi olmuştur. Eski geleneksel/konvansiyonel siyasal sosyoloji algısından oldukça yeni bir duruma geçiş yapıldığını gösteren bu durum, ideoloji, değer ya da etnisite-merkezli bir kimliksel algıdan, keskinliklerin yumuşatıldığ 1 ve bu anlamda da bu sayılan parametrelerin eski önemlerini yitirdiği bir yeni duruma geçişin bir göstergesi olarak okunabilir. Zira insan olmak ile alakalı durum, aslına bakılırsa soruda sorulsa dahi, siyasal sosyoloji bağlamında ve dâhilinde değerlendirilmemesi gereken, bu yönüyle de bu kadar yüksek bir cevap oranına sahip olmaması gereken bir durum olmalıdır. Sanırız cevap tercihlerindeki bu şıkka verilen bu rağbet, bu yönüyle cevap verenlerin, bu meselelere dair bilgi ve perspektifinin yetersizliği kadar, küresel bir yeni kültürel havzanın, zihinsel ve felsefi anlamda oldukça etkisi altında olunduğunun da net göstergesidir.

O halde burada, siyasal kimliklerin eski öneminin korunup korunmadığına dair bir çıkarımda bulunulabilir mi? Kimlik ihtiyacı, bireylerin başkalarından ayrışan yönlerine olan vurgu ile anlam kazanan bir olgu olarak nitelendiğinde -ki genel kabul böyledir-, yeni bir diyalektik biçimi olarak benzerlik ile farklılık uçları arasındaki bir salınım gündemimize girmiş durumdadır. Bu anlamda geleneksel/konvansiyonel içeriği ve tanımı ile siyasal kimliğin, başkalarından din, dil, etnisite, mezhep, ideolojik pozisyon gibi kategoriler temelinde ayrışmayı ve farklılık arayışını çağrıştıran boyutuna, artık yeni bir boyut olarak benzerlik arayışının (Bilgin, 2007, s.19-20) da dâhil olduğu yeni bir kavramsal-entelektüel süreçten bahsetmek gerekmektedir.

Yine aynı raporda dikkat çeken bir diğer nokta, gençliğin bu kez modern-gelenek düzlemindeki kimliksel aidiyetlerini, yüzde 72 gibi çok ciddi bir oranda "biraz modern-biraz geleneksel” olarak tanımlamalarıdır. Bu aynı zamanda kendini ne geleneksel ne de modern olarak tanımlamak demektir. Bir nevi bir hibrid modeli çağrıştıran bu durum, gelenek ile modern arasında nasıl bir konumlanma tutulacağının, esasında küresel ölçekte yaşanan yerel bir yansımasıdır.

Siyasi, ideolojik ve dini kimlikler bakımından meseleye bakıldığında ise, sonuçlar, ilk 5 'te; yüzde 43 ile "Müslüman”, yüzde 31 ile “ilerici”, yüzde 29 ile "Atatürkçü”, yüzde 23 ile "laik” ve yüzde 22 ile "İslamcı" şeklinde tezahür etmiştir. Bunun, gelenek-modern düzlemindeki karşıllı̆̆ ise: kendisini en yüksek düzeyde modern olarak niteleyenler; yüzde 30,8 ile ateist, yüzde 15 ile devrimci, yüzde 14,4 ile feminist, yüzde 13,5 ile sosyalist kimliğine sahip olanlardır. Kendisini en yüksek düzeyde geleneğe bağlı olarak niteleyenler ise; yüzde 19,3 ile muhafazakâr, yüzde 18,7 ile milliyetçi, yüzde 18,2 ile İslamcı kimliğine sahip olanlardır.

Tipkı bunun gibi, laiklik-İslamcılık-dindarlık bağlamında olaya yaklaşan TESEV raporu ise, yukarıdaki rakamların yanı sıra, bir başka parametreden olaya dair sonuçlar sunmaktadır. Buna göre, 0'dan 10'a, bir uçta laiklik diğer uçta İslamcılığın olduğu bir skalada gençliğin ortaya koyduğu barem değeri 5,5 şeklinde tezahür etmiştir. Bu şu demektir: hemen hemen bunların ortasında bir pozisyonda bulunulduğu anlamına gelmektedir. Belki de siyasal-ideolojik posizyonlanmalardaki 
bahsi edilen niteliksel değişim, kendisini en belirgin biçimde bu skalada göstermektedir. Dindarlık konusundaki rakamsal göstergede ise genç, kendisine 6,5 verirken; annesine 7,7; babasına ise 7,4 vermektedir. Bu göstergeler dâhilinde son bir nokta ise, söz konusu bu laikİslamc1-dindar pozisyonların, etnik kimlik aidiyetleriyle nasıl bir ilişkisellikte olduğudur. Buna göre; anne babasıyla Kürtçe/Zazaca konuştuğunu ifade edebilen bir gencin "laiklik-İslamcıllk" skalasındaki değeri 6,9'a çıkmaktadır. Yine bunun gibi, skalada dindarlık konusundaki rakam da artmaktadır. Bu genç, dindarlık hususunda kendisine 7,7 verirken; annesine 8,8; babasına ise 8,5 vermektedir. Bu durum, Kürt/Zaza etnik kimliğine mensup olan gençlerin, kimliksel aidiyet anlamında, ortalamaya oranla daha İslamcı ve daha dindar oldukları ya da bu iki tür ("İslamcılıkdindarlık" ile "Kürtlük-Zazalık") arasında, diğer kimliksel parametrelerin kendi aralarındaki ilişkiye görece daha yakın bir ilişki olduğu anlamına gelmektedir. Diğer bir deyişle, Kürt/Zaza köken ile dindarlık değerlendirmeleri, "laik-İslamcı" ayrımında "İslamcı" uca yakınlıkla eş anlamlıdır.

\section{Sonuç}

Batı düşüncesinin pozitivist geleneği üzerinden yükselen bir düşünme biçiminin son yüzyll boyunca siyasal ve toplumsal tasavvurları şekillendirmesi, gerek doğu gerek batı toplumları açısından kısıtlayıcı ve uyuşmaz etkiler yaratan bir duruma dönüşmüştür. Buradan çıkışın stratejisini ise yine, kendi içerisinde niteliksel kırılma yaşayarak bir post-pozitivist düşünme metoduna evrilen Batı düşüncesi kavramsallaştırmıştır. Postmodernizme atfedilen cazibe, işlevini tam da bu pozitivist gelenek ile olan "hesaplaşma” perspektifinden almaktadır. Geleneksel aidiyetler ve disipline edici normatif çerçevelerden büsbütün azade, kendi merkezinden hareket eden yeni bir tür tasavvurun başlangıç noktasını oluşturduğu yeni bağlam, Aydınlanma aklını da derinleştirerek yeniden üretmiş; kendisine göreliliğin, muğlaklığın ve parçacılığın ekseninde bir anlam haritası çıkarmıştır. Küreselleşmenin, kültür endüstrisinin ve post-Fordist yaşam formunun eklemlendiği yeni kültürel, iktisadi ve siyasi anlam havzasında siyasal ve toplumsal kimliklere de yeni bir düzlem inşa edilmektedir. Zira insanlar artık kimliklerini tanımlarken, tek boyutlu bir tasavvurla değil, birden çok parametrenin etkidiği bir zihin dünyasında tanım yapmaktalar. Göreli ve geleneksel-toplumsal aidiyetlerden kopuk bir zihin formunun kendisi artık başlı başına bir realiteyken, küreselleşmenin ve kültür endüstrisinin kültüre, ekonomik yaşama ve siyasal tasavvurlara yüklediği niteliksel dönüşüm, insanların hayatın hemen tüm formlarına bakışlarında da ciddi bir başkalaşım doğurmuştur. Bu, siyasal-toplumsal alışkanlık ve ilişkilerin doğasının dönüşüme uğraması durumudur. Artık kişisel yaşam alanları da, kamusal ilişkilere rengini veren karakteristik de bu yeni düşünme, hissetme ve anlama dünyasının etkisinde dönüşüme uğramaktadır. Bir taraftan ulus-devlet mantalitesini siyasal, kültürel, iktisadi ve sosyolojik bakımdan aşmadan küresel bir ufka ulaşılamayacağı; öte yandan, yeni bir iktisadi paradigmanın öngördüğü şekilde, hayatın hemen her alanının ekonominin birer fonksiyonuna dönüşerek bireye ve ekonomiden kültüre hemen her alanda bireysel çerçevede gelişecek inisiyatiflere sorgusuz bir alan açılmadan özgürlüğe ulaşılamayacağı tezi, bu ufka yol 
alınırken heybelere konan en önemli argümanlardır. Kimlik olgusu da bu süreçteki merkezi odak unsurlardan biridir.

Kültür ile ekonominin bu yeni ilişkisel denklemi, kültürel kimliklerde metalaşma ve endüstriyelleşme yolunda bir başkalaşım doğururken, kültür-siyaset ilişkisi de bu sürecin diğer boyutunda kendisine bir yer bulmaktadır. Yeni siyasal kültüre işaret eden bu boyutta, siyasal olmanın içeriği ve tanımı bütüncüllükten parçacılığa geçmek suretiyle, bundan böyle va’z edici normatif yüklemeler yapamaz hale gelmiş, ancak -yeni - kültürel eğilimler tarafından belirlenecek bir unsura indirgenmiştir. $\mathrm{Bu}$ ise siyasa ile kültürün, kimlikleri belirleyici etkisindeki rollerini tersine çevirmiştir. Artık kültürel eğilimler ve kültürel dönüşümler, siyasa’yı da belirleyecek şekilde, siyasal-toplumsal-kültürel kimliklerin başat belirleyici aktörüdür. Yeni kültürel dünya ise postmodernizmin bireyciliği ve göreliliği, küreselleşmenin emici tektipliliği ve post-Fordist yaşam biçiminin kültür endüstrisi ile bütünleşerek oluşturduğu hayatı metalaştıran tasavvuru ekseninde bir anlam dünyasına işaret etmektedir. Kimlikler, işte bundan böyle bu kaygan düzlemde rotasını arayan, bir yandan yeni alt-kimliksel düzlemler yeşerirken bir yandan da özgünlüklerini kaybederek hükmedici/icbar edici bir küresel dominasyonun hâkimiyetine girmek durumuyla karşı karşıya kalan bir sıradanlık unsuruna dönüşme riskiyle karşı karşıyadır.

Siyasal kimliklerde olduğu gibi ideolojik pozisyonlanmalarda da benzer etkilerin olduğu söylenebilir. Postmodern felsefenin siyasal alana en büyük vaadi tarafsızlık vaadi olduğuna göre, oluşacak yeni siyasal konumlanmaların da buna göre şekillenmesi beklenir. Oysa bu tarafsızlık iddiası, bir başka boyuttan, her türden siyasi yönelime eklemlenmeye kapı açabilecek yeni bir tür geçişken/eklektik siyasal tasavvur da üretir ve söz konusu iki durum eşanlı olarak yürür. $\mathrm{Bu}$ ise, yoğunlukla iddia edildiğinin aksine çoğulculuğa değil, siyasa tasavvuruna dair bulanık ve karmaşık bir zihinsel forma işaret eder. Türkiye’nin bu serüven içerisindeki yeri ise, şahsına münhasırdır. Cumhuriyet'in ilk yıllarından beri süregelen ulus inşası fikri, modern dönemin kalıplaştıran, dolayısıyla da her boyuta direkt müdahil olan bir tasavvur doğurmuş, bunun siyasaltoplumsal kimliklere yansıması ise icbar yoluyla yaratılmaya çalışılan bir vatandaş prototipi olmuştur. Ulusçu idealar ve ideolojik endoktrinasyon, bunun en belirleyici alt parametreleri olarak yıllar boyu modern Cumhuriyet tarihinin kimlik siyasetine doğrudan müdahil oluşunun argümantatif unsurları olarak işlev görmüştür. 1980’lere dek manzara bu şekilde iken, bahsi edilen kültürel-siyasal-iktisadi dönüşümün izlerini derinden sirayet ettirici bir süreç olarak yaşayan Türkiye’de 1980’lerle birlikte çok şey değişmeye başlamıştır. Resmi ideolojilerin nasıl aşılacağı, siyasal-toplumsal kimliklerin bu ideolojik merkezin boyunduruğundan nasıl kurtulacağı ve özgün kimlikler olarak siyasal alana ne şekilde yayılabileceği, temel sorular halini almıştır. Başlı başına niteliksel bir dönüşümü beraberinde taşıyan bu yeni anlam dünyasında, sivilleşmenin, demokratik normların, piyasa toplumunun ve insan hakları nosyonunun etrafında gelişen bir yeni siyasa kendisini bulmaya başlamıştır. Aynı zamanda bünyesinde geçmişe dair bir tepkiselliği de barındırması, bu dönüşümsel sürecin kendi içerisindeki renklerine dair bir ufuk da sağlamaktadır. Bu sürecin artıları ile eksilerini birlikte değerlendirdiğimizde karşımıza yine bulanık bir fotoğraf çıkmaktadır. Bir taraftan kimliklerin, devletin dayattığı çerçevenin dışına çıkmak suretiyle çözülme yaşaması özgür, özgün ve hür düşünme biçimi için yeni bir imkân ve 
alan açarken, bir taraftan ise kimliklerin savrulma ve - bu kez tersten - çözülme ihtimalinin hiç olmadığı kadar mümkün hale geldiği kaygan bir zihinsel formata da kapı açmaktadır. Bunun tehlikesi ise, inşacı değil salt bozucu-yıkıcı bir anlam dünyasının, özellikle gençlik arasında tercih edilir hale gelmesi durumu olacaktır. Zira Türkiye, 1980 darbesi sonrası bir yandan depolitizasyon sürecini bilinçli şekilde tecrübe ederken, bir yandan da bu yeni anlam dünyasının ${ }^{1}$ farklı ve öngörülemez komplikasyonlarını test etmek durumunda kalmış bir manzara sunar.

O halde 1980 sonrası dönemin bu bambaşka mahiyete sahip yapısı, sahadaki siyasal-toplumsal kimliklere olan karşılığının ne olduğu sorusunu sorarken, bizi özellikle 30 yaş altı yaş grubunun zihinsel yansımalarına dair bir fotoğraf çekme zaruretine götürmesi gerekmektedir. Zira küresel yeni durum olarak tarif edilen bağlamın etki alanını, tam da bahsi edilen kuşakta hissettirmesi beklenir. $\mathrm{Bu}$ anlamda gençliğin kendisini tanımlarken ve bu tanımdan yola çıkarak siyasal ve kültürel gelişmelere yaklaşırken başvuracağı temel referans noktası olarak kimlik, nasıl ve ne şekilde algılanıp tarif edilmektedir? Bunun söz konusu süreçle ilişkisi var ise eğer, yönü nasıldır? Bu sorulardan yola çıkılarak elde edilen niceliksel bulgular ${ }^{2}$ göstermektedir ki, genç kuşak arasında daha küresel, daha liberal, eşanlı olarak ise daha "direnişçi" ve daha bölgeselci bir kimliksel eğilim söz konusudur. Zira "Türklük” vurgusunun yerini, daha üst bir kimlik olarak "Türkiye Cumhuriyeti vatandaşlı̆̆ı" vurgusuna; ve ideoloji merkezli tanımlamaların yerini, keskinliklerin yumuşatıldığ 1 ve eski parametrelerin öneminin yitirildiği bir yeni anlam dünyasını işaret eden, soyut, muğlak ve doğrudan siyasallığa taalluk etmeyen bir tanımlama biçimi olarak "insan" tanımına bırakması, küresel yeni kültürel havzanın zihinsel ve felsefi etkisini anlamak bakımından dikkate değerdir. Benzer biçimde, yapılan “Türk ve Kürt” tanımlamaların toplamının yüksek oranda çıkması, bölgeselcilik/etnikçiliğin halen daha gençlik arasında belirli bir alıcısının olduğunu gösterirken; bundan daha dikkat çekici olan, genç kuşak arasında toplumun geneline göre "Türklük" vurgusunun daha düşük, "Kürtlük" vurgusunun ise daha yüksek oluşudur. Bu ise, "direnişç" temeldeki kimliksel aidiyet tanımlamalarını işaret eden bir durum olarak belirdiği kadar, Türkiye siyasal geçmişi açısından bir tepkiselliğe işaret etmesi bakımından da anlamlıdır. Zira Türkiye’nin yukarıda bahsi edilen tarihsel sürecinin kimliklere olan -pozitif ve negatif etkiler olarak - çift yönlü yansımasında bu sonucu görmek çok da şaşırtıcı olmamaktadır. Yani burada kimliksel tanımlar bir yandan devlet karşısında "direniş"i ve özgürleşmeyi ararken, bir yandan da savrukluğa açık bir kaygan zemin oluşumu söz konusudur. Daha geniş ve teorik çerçevede ise, postmodernizmin parçacı etkisi, alt bölgesel kimliklere olan ilgi şeklinde kendisini göstermektedir. Yani gerek teorik çerçeve, gerekse Türkiye özelindeki tarihsel süreç, ortaya çıkan sonucu teyit etmektedir. Bir diğer tartışma alanı olarak "modernlik-geleneksellik" çizgisine dair ortaya çıkan sonuç, hibrid bir modeli çağıran "biraz modern-biraz geleneksel" tanımlama

1 Bir taraftan depolitizasyonu konuşurken, bu yeni anlam dünyasının - yapısal olarak - siyasallık dışı bir olgu ve süreç olmadığını da ayrıca belirtmemiz gerekmektedir.

2 Bu noktada, konuya dair yakın geçmişte yapılan iki büyük gençlik saha çalışmasının raporları değerlendirmeye alınmıştır. Söz konusu çalışmaların, konu dâhilinde şu ana dek yapılmış en kapsamlı çalışmalar olması, aynı zamanda karşılaştırmalı bir analizi de dışlamayarak, teorik zeminin sahada karşılığının ne olduğuna dair olabildiğince net bir fotoğraf sunmaktadır. Bununla birlikte, her niceliksel/niteliksel çalışmada olacak hata payını elbette göz ardı etmemek gerekmektedir. 
biçiminin oranının yüksekliğidir. Bu ise, kimlik ihtiyacının ayrışma olduğu kadar aynı zamanda birbirine yakınsama ve benzerlik arayışı olduğu tezini doğrulayan, siyasal spektrumda ve kültürel yaklaşımlarda merkezlik idealinin postmodern anlam havzası içerisinde dünyada farklı ülkelerde neden bu kadar yaygın ve sürdürülebilir bir örnek sunduğunu açıklayan bir durumdur.

Nihayetinde, tüm bu sonuç ve bulgular ışı̆̆ında söylenmelidir ki gençlik, siyaset ve siyasal sosyoloji anlamında siyasal kimlikle olan ilişkisini kurarken, küresel kültür-geç kapitalizmin ortaklaşa inşa ettiği, felsefi kaynağını postmodernizmden alan bir felsefi-zihinsel durumla oldukça sıkı bir etkileşim içerisindedir. Bu ise, liberal bir çerçeve içerisinde, kimlikler arası geçişgenliğin artıp, farklılıkların azaldığı bir zihinsel havuzdan düşünmek, aidiyet tanımlamak ve beraberinde, beslenmek demektir. Bununla birlikte söz konusu bu durumun, başlı başına ve kategorik olarak kötümserliğe kapı açmaması gereğiyle birlikte, küresel ve - doğal olarak - yerel çaptaki felsefi ve kültürel zeminin iyi anlaşılmasının; ona göre verilecek cevapların da, bugünün atmosferi sskalanmadan ve nihayetinde gençlik kavramının yapısal olarak içerdiği biyolojik, psikolojik ve sosyo-psikolojik hususiyetler göz ardı edilmeden geliştirilecek bir perspektiften çıkmasının zaruri olduğu açıktır. 


\section{Kaynakça}

Aslan, S. ve Yılmaz A. (2001). "Modernizme Bir Başkaldırı Projesi Olarak Postmodernizm”. Cumhuriyet Üniversitesi İİBF Dergisi. C.2 S. 2. s.93-108.

Baudrillard, J. (2003). Simulakrlar ve Simulasyon (Çev. Oğuz Adanır). İstanbul: Doğu Batı Yay.

Bilgin, N. (2007). Kimlik İnşası. Ankara: Aşina Kitaplar.

Carr, Edward H. (1957). The New Society. Boston: Beacon Press.

Çağlar, N. (2008). "Postmodern Anlayışta Siyaset ve Kimlik". Süleyman Demirel Üniversitesi İİBF Dergisi. C.13 S.3. s.369-386.

Çarkoğlu, A. ve Toprak, B. (2006). “Değişen Türkiye'de Din, Toplum ve Siyaset”. İstanbul: TESEV Yayınları. Featherstone, M. (1996). Postmodernizm ve Tüketim Kültürü (Çev. Mehmet Küçük). İstanbul: Ayrıntı Yay.

Foucault, M. (2016). Özne ve İktidar (Osman Akınhay, Işık Ergüden). İstanbul: Ayrıntı Yay.

Gramsci, A. (1971). Selections from the Prison Notebooks. New York: International Publishers Co.

Habermas, J. (1994). The Philosophical Discourse of Modernity - Twelve Lectures. Oxford: Polity Press.

Habermas, J. (2001). İletişimsel Eylem Kuramı. (Çev. Mustafa Tüzel). İstanbul: Kabalcı Yayınevi.

Heywood, A. (2007). Siyaset (Çev. B. Özipek-B. Şahin-M. Yıldız-Z. Kopuzlu-B. Seçilmişoğlu). Ankara: Adres.

Jameson, F. (2008). Postmodernizm ya da Geç Kapitalizmin Kültürel Mantığı. (Çev. Abdulkadir Gölcü). İstanbul: Nirengi Kitap.

Kahraman, H. B. (2007). Postmodernite ile Modernite Arasında Türkiye. İstanbul: Agora Kitaplığı.

Küçük, M. (1994). Modernite Versus Modernite. Ankara: Vadi Yay.

Sosyal, Ekonomik ve Kültürel Araştırmalar Merkezi. (2013). "Türkiye’de Gençlik: Gençliğin Özellikleri, Sorunları, Kimlikleri ve Beklentileri”. İstanbul: SEKAM Yayınları.

Şaylan, G. (2002). Postmodernizm. Ankara: İmge Yayıncilık.

Şaylan, G. (1996). Çağdaş Düşünce Akımları: Postmodernizm. Ankara: TODAİE Yayınları.

Topçuoğlu, A. ve Aktay Y. (1996). Postmodernizm ve İslâm, Küreselleşme ve Oryantalizm. Ankara: Vadi Yayınları.

Üstel, F. (2014). Makbul Vatandaşın Peşinde. İstanbul: İletişim Yayınları. 